\title{
Mr Kennedy and consumerism
}

\author{
Dame Elizabeth Ackroyd Chairman of the Patients Association
}

\begin{abstract}
Author's abstract
I welcome Mr Kennedy's general approach, but query whether the concept of consumerism is so closely applicable to medical care as he maintains. However, in particular aspects, especially the handling of complaints, his criticisms echo those made by the Patients Association. Finally, I detect some ground for hope in the more enlightened attitude creeping in to the education of the medical student.
\end{abstract}

Much of what Mr Kennedy said in his Reith Lectures warmed my heart. If, day after day, one hears, as we do at the Patients Association, from people who are dissatisfied with the treatment they have received in hospital or from their doctors, the force of Mr Kennedy's criticisms of the medical profession strikes a very sympathetic chord. We do, however, recognise that we hear only one side of the story. We recognise also that evidence from field work indicates that while there is much that is chastening to doctors, nonetheless most patients most of the time rub along all right with them and with hospitals (I). Doctors pretty consistently maintain their position as top or near top of the public esteem league, always outpointing lawyers incidentally.

Mr Kennedy argued in his sixth lecture that consumerism is with us: 'The doctor has the choices only of accepting it willingly and cooperating or accepting it unwillingly' (2).

I think that he may overestimate this. There is a view among some close observers of the consumer scene that consumerists have, at any rate for the time being, lost some of their clout. Industry and commerce now feel bold enough to argue publicly that the rules and regulations protecting consumer interests which have been promulgated in the last couple of decades are now pushing up the cost of production and distribution to the detriment of the consumer himself. Against this background, the invocation of consumerism by $\mathbf{M r}$ Kennedy in the context of doctor-patient relationships, may not perhaps be very helpful to the patient's side of the equation.

In any case, I have some doubts whether the traditional consumer attitudes are all closely applicable to the medical scene. Mr Kennedy looks at consumerism from a lawyer's perspective. He describes as its goals, the provision of financia $\vec{\Phi}$ compensation, when needed, to injured patients, and disciplining of bad doctors. Certainly patient want these things should circumstances arise where they would be appropriate, but from my experience, people's attitude to their medical care is far from being so closely focused. Judging from the kind of complaints and representations received by tho Patients Association, patients in general want the? doctors to be nice to them, to communicate with them in an open and informative way, and to listeg without rancour to any dissatisfaction which the may express about their medical treatment. To that extent they exhibit the usual consumer attitudeक But they do not want to be able to shop around in $\mathbf{a}$ free competitive market for medical service£ Perhaps this is not a necessary ingredient of what Mr Kennedy meant by consumerism and I ang presenting a travesty of his argument; but it is think what most people in the consumer worlo would accept as the hallmark of their platforna Having said this, the proposals which Mr Kenned puts forward in his sixth lecture (2) are certainf ones which I support, and which indeed the Patients Association has advocated for a long time I do not think that Mr Kennedy would claim that he was putting forward new ideas, and his advocae of them in the prestigious context of the Reith Lectures is much to be welcomed.

The lack of proper complaints procedures hospitals is rightly criticised by Mr Kennedy. Hepe is an area where purchasers of goods and services join hands with patients; but only up to a poin? since while one can be offered a new washing machine or a free repair for a faulty one, or replacement holiday, such remedies are not available in the case of a wrong diagnosis or an extended and unexplained waiting time for an appointment What the patients want is a frank explanation of what went wrong, and if serious damage has bee done to health and livelihood, a readily available and quick means of obtaining compensation. None of this exists at present. Since Mr Kennedy gave his lectures the BMA has put forward and the Deparm ment of Health and Social Security has endorsed, scheme for providing information, and it is hoped by the medical profession, reassurance, to people querying a clinical judgment which has resulted in some damage to the patient (3). I believe that this is in fact a soft option for doctors, designed to staie 
off the intrusion of lay assessment of clinical matters, since only doctors will be involved in the consideration of a patient's complaint. I, like $\mathbf{M r}$ Kennedy and other distinguished authorities (4), (5), believe that the Health Service Commissioner should be able to investigate complaints involving clinical judgment.

To doctors 'medical audit' is another red rag to a bull. I should like to see a system akin to HMIs in the schools world. The 'inspectors' would be drawn from the medical profession (as is, in part, the Health Advisory Service which monitors conditions in long-stay hospitals); they would not have the power of life and death over doctors, but one would expect their opinions and recommendations to be taken seriously. The Patients Association put this suggestion to the Merrison Committee of Inquiry into the Regulation of the Medical Profession (6), but it fell on stony ground - like so many other proposals from outside which doctors regard as threatening. Mr Kennedy is so right about their attitude in general.

But there is hope. The medical schools are becoming more enlightened in their curricula; the patient no longer is regarded in them simply as a system of bones, nerves, flesh and so on, but also as a fellow human being. In addition consumerism in the general environment (even if less pervasive now than formerly) does rub off on medical students and young doctors, and on other professions, tradesmen and industrialists, so that in that sense, but by osmosis rather than through an act of conscious choice by doctors, consumerism will have its effect.

\section{References}

(I) Raphael W. Patients and their hospitals. London, King Edward's Hospital Fund, 1969. Patients satisfaction survey 1972-73. United Manchester Hospitals: Patients Committee. Cartwright A. Patients and their doctors. London, Routledge and Kegan Paul, 1967. Cartwright A, Anderson R. Patients and their doctors. Royal College of General Practitioners, 1979.

(2) Kennedy I. Consumerism in the doctor-patient relationship. The Listener 1980 Dec II: 777-780.

(3) Department of Health and Social Security circular HC (8I) 5, April 198I: Annex Part II.

(4) Ackroyd E. Complaints against the medical profession. Poly Law Review I98I ; December.

(5) First Report from the Select Committee on the Parliamentary Commissioner for Administration Session 1977-78. House of Commons. 16 November 1977 HMSO.

(6) Report of the Committee of Inquiry into the Regulation of the Medical Profession. (The Merrison Report). Cmnd 6018. London: HMSO, 1975.

\section{Continued from page 179}

She was admitted for hysterectomy only to discover that she was five weeks pregnant. She was delighted with this news. Unfortunately her new partner left within a few weeks of this discovery. The patient therefore returned with a request for termination of pregnancy using the same grounds as first used in her request for sterilisation.

She was referred to the medical social worker for reports and the opinion of a second gynaecologist was obtained. Both felt that she had been a victim of circumstances rather than indecision and that an additional child would place an intolerable strain on her at a time of great uncertainty. Nonetheless, they were impressed by her determination and independent nature. It was therefore felt that she had good grounds for her request and termination was performed forthwith.

\section{Comment}

This lady made a series of decisions with the support of medical staff which were subsequently found to be wrong. The dangers of sterilisation under 30 and in relation to an unstable marriage (although undetected in this case) are well recognised (2). However, it is rare to see patients who have undergone reversal of sterilisation requesting termination of pregnancy or further sterilisation.
It is significant that the patient had a delay of 18 months between presenting her case for reversal and the operation, so she had considerable time to reconsider. It is difficult to see how counselling could have been improved to avoid this series of events, although the outcome might possibly have been predicted. Suppose the actual course of events had been predictable, should the patient nevertheless have been allowed to make her own decision, as Kennedy advocates? Would this be a proper use of scarce NHS resources?

While there is no question of apportioning blame, this case would be welcome evidence to those who oppose the full availability in the National Health Service of operations for social, cosmetic or other indirect medical indications. In fact it is presented to illustrate the difficulties in decision making for such operations, the unpredictability of social circumstances, particularly marital relationships, and to question the appropriateness of leaving difficult decisions to patients rather than to their doctors.

\section{References}

(I) Kennedy I. Consumerism in medicine. The Listener I980 Dec II; 777-780.

(2) Winston R M L. Why 103 women asked for reversal of sterilisation. British medical journal 1977; 2: 305 . 